\title{
LAUGHING CHILDREN AND FUNNY CHILDREN: LAUGHTER AND EARLY CHILDHOOD $^{1}$
}

Original scientific paper Received: 15. 11. 2016 Accepted: 2. 1. 2017.

DOI: $10.15176 /$ vol54no102

UDK 81'23-053.2:82.09-7 398.23-053.2

\author{
JOVAN LJUŠTANOVIĆ \\ Preschool Teacher Training College, Novi Sad
}

LJILJANA PEŠIKAN-LJUŠTANOVIĆ

Faculty of Philosophy, University of Novi Sad

Laughter is a significant part in the lives of children and youth. Statistically speaking, children laugh much more than adults. Our paper deals with preschool children's laughter, the ways children laugh and make each other laugh in everyday communication, and the ways in which children of this age make adults laugh. We will look into children's laughter, ranging from spontaneous expression and verbalization of good mood (a phenomenon that Korney Chukovsky refers to as "ekikiki") through children's nonsensical puns, various types of phonetic and semantic scrambling and distortion of words and phrases, euphonic games and puns to children's jokes. We will try to show how children's laughter-making oral literary complex (constituted of specific genres and stylistic forms) is expressed, and how this expression, mutatis mutandis, facilitates the formation of a social community of laughter of preschool children. On the other hand, preschool children, with their naïve thinking, establishment of unusual and unexpected symbolic relationships and misunderstanding of social relations between adults, often make adults laugh. This phenomenon of "children's mouths" has its reflexes in oral genres (jokes) as well as in narrative subjects and focalizers in written literature (poetry, short story, novel).

Keywords: narrative subject, childhood, laughter, community of laughter, children's mouths

${ }^{1}$ This article is to appear in the edited volume entitled Humor u svakodnevnoj komunikaciji (Humor in Everyday Communication) (Institute of Ethnology and Folklore Research, 2017), and is published here with the permission of the volume editors. 


\section{CHILDREN'S LAUGHTER - THEORETICAL STARTING POINTS}

The way we have framed the topic of our paper means that we are - to a considerable extent - venturing into the domain of conjecture and speculation. ${ }^{2}$ An attempt to systematize children's laughter from a research perspective, i.e. dealing with the questions of when, how, why and whence children laugh, turns out not to be a simple one. Although children, and especially preschool children, laugh much more than adults, an adult is very much left at the outskirts of their laughter: they can hear it, may sometimes realize what its reasons are, but the mechanisms on which it rests - complete insight into the ways in which children laugh and make each other laugh in everyday communication - from the adult's perspective, to some extent remain in the domain of conjecture, interpretation, paraphrase. Children themselves explain their laughter sparingly and unwillingly, mostly by retelling or even "playing out" the funny situation. ${ }^{3}$

Principled doubts "in the very definability of the subject" (Perišić 2013: 17) which arise any time when laughter is studied, are even more serious when children's laughter is at issue. The dual nature of laughter as a literary-theoretical category and a psychological phenomenon that encompasses "objectivity and subjectivity" (ibid.: 45) is difficult to capture using the framework of scholarly conceptual discourse. Even if we accept that laughter may be discussed only from a theoretically intuitive point of view, we are faced with the fact that, in the case of children's laughter, the very object of laughter (what children experience as deliberately or non-deliberately humorous) is difficult to understand from an adult point of view; the same is true of its quality (what is humorous and funny in the specific object), and particularly the laughing subject. As a subaltern social group (Lansdown 1994: 35; Tomanović 2004: 22; Radović 1959: 11)4 children are observed from the outside, from the point of view of the adult, who does have some experience of childhood, but which has been significantly altered by the nature of one's memory and the workings of time.

What is more, an adult can relatively easily reach the conclusion that a laughing child is not able to understand humor as a higher aesthetic phenomenon (Hegel 1986), with

${ }^{2}$ The part of the research conducted by Ljiljana Pešikan-Ljuštanović was conducted within the project Aspekti identiteta i njihovo oblikovanje u srpskoj književnosti (Aspects of identity and their formation in Serbian literature) (Project number 178005), under the direction of Professor Gorana Raičević, principal investigator, at the Department of Serbian Literature, Faculty of Philosophy, University of Novi Sad, funded by the Ministry of Education and Science of the Republic of Serbia.

${ }^{3}$ Upon coming back from preschool, a girl said that all the children were laughing, and when asked why, she started making faces, stumbling and falling, probably repeating the gag that made her laugh, or maybe trying to be funny herself.

${ }^{4}$ Poet Dušan Radović, in his book Dete i knjiga (The Child and the Book) said: "Childhood is not really as happy a time as may seem to certain educationalists and agitators. Children are disempowered, inferior, limited. There is never a time when one wants to do so much more and can only do so much less than during childhood. The best moments of childhood, playing and sleep, are interrupted by others. Because it was late, because it was cold, because guests were coming, because you had to do homework" (Radović 1959: 11). 
children's laughter frequently having the "character of utter vulgarity", which can shock "any, even slightly sophisticated sensibility" (Souriau 1999: 1926 ff; cf. also Hauser 2005: 188-192), i.e. it does not have a "positive esthetic value", but is "the laughter of vulgarity" (Souriau 1961: 209).

As opposed to these views, according to some opinions, human laughter is most profoundly related to childhood. For instance, Sigmund Freud developed his theory of the joke (Witz), recognizing childhood as the origin of much of human laughter. According to Freud, laughter originates from the "economy in expenditure", which is a result of overcoming a "critical obstacle", i.e. an indirect, socially acceptable lifting of the human inhibition by "criticism and reason" (Freud 1969). Freud draws attention to child play as the origin of any later human laughter. He recognizes the cognitive function of child play, but, above all, stresses the pleasure (joy, laughter) that play produces - the "pleasure that is a result of repetition of what is similar, of finding what is familiar once again, of similarity of sound, etc." (ibid.: 131). According to him, human laughter, to a large degree, originates because of "a reestablishment of old freedoms" and "relief from the pressures of intellectual education" (ibid.), and it is frequently an indirect way for an adult to renew some of the pleasure permanently lost during childhood.

In any case, however we approach the phenomenon of children's laughter, either by denying it its anthropological and esthetic status or by asserting its importance in the genesis of laughter as a general human phenomenon, we remain within the bounds of theoretical intuition. Keeping this paradox in mind, we ventured into our study of preschool children's laughter. We used the following statement by Henri Bergson as our starting point: "Our laughter is always the laughter of a group. [...] However spontaneous it seems, laughter always implies a kind of secret freemasonry, or even complicity, with other laughers, real or imaginary" (Bergson 2004: 11). Our aim was to provide at least a rough description of how the community of laughter emerges in preschool children (aged 3 to 7), more specifically, how different communities of laughter spontaneously arise: communities of preschool teachers, when they laugh at what children and saying and doing, communities of preschool teachers and children, and communities of only children. ${ }^{5}$

\section{LAUGHTER IN PRESCHOOL - THE STUDY}

In the period from 1 to 15 October 2015, we distributed the following questionnaire to preschool teachers ${ }^{6}$ in the "Radosno djetinjstvo" (Happy Childhood) Preschool Institution in Novi Sad:

${ }^{5}$ Our research is to a limited extent comparable to the much more complex and comprehensive study into children's humor which, also, included "the early phase of humor development" (Hauser 2005: 65-88).

${ }^{6}$ Although our questionnaire was not gender exclusive, the answers we happened to get were only from female teachers. 
Please fill in the following questionnaire about spontaneous laughter of children in preschool. We are not interested in activities that are part of your educational curriculum (interpretations of poems and stories, plays, role playing, pre-planned games) which aim to cause joy and laughter. We are interested in spontaneous situations where children (children and teachers) laugh.

1. Try to remember a spontaneous situation (what the children said and did) which made you laugh, when children who were present during the situation did not laugh. Give a short description:

2. Try to remember a spontaneous situation (what the children said and did) which made you and the children who were present laugh. Give a short description:

3. Remember a spontaneous situation (what the children did and said) that made other children laugh (at least two other children in addition to the child saying or doing something), without you finding the entire situation funny. Give a short description:

We handed out 148 questionnaires, and received 103 responses. Although enough answers were collected for a statistical analysis, the qualitative idea behind the questionnaire, subjectivity in experiencing humor by the respondents and the interpreters of the questionnaire (in $7 \%$ of the responses we could not understand what could be taken as funny in them), alongside the mentioned doubt "in the very definability of the subject", presented a hindrance to defining the variables that would be the subject of statistical interpretation, and left us permanently, it seems to me, within the bounds of theoretical intuition.

The responses to certain questions make it very clear that the respondents have very different views of humor. The preschool teachers mostly laugh at "children's mouths", i.e. at naiveties (a very diverse category, which refers to about half of the collected examples). These are children's statements and actions that a teacher experiences as a joke (the "technique" makes it look like a joke), although children, because of their lack of knowledge and limited experience, say it and do it with serious intent, and do not achieve the pleasure that is normally achieved by the person who makes other laugh by joking (Freud 1969: 188). For instance, a child who did not want to sing with the other children, but still joined the children singing, said: "My brain did not want to sing, but my mouth started all by itself". The child was not joking, but was trying to explain its illogical behavior, however to an adult it resembled a joke, and $\mathrm{s} /$ he laughed. These examples often clearly reflect the child's and his/her family's preoccupations and project the psychological state of the child. For instance, a boy whose family is expecting a baby said to the teacher: "I am going to have a baby. It is now in my mom's belly. When it grows, it will be in my belly". The child's transductive reasoning serves not only to explain the process that the child does not yet understand, but is also a way for the child to, in one way or another, assimilate a new social situation caused by his mother's pregnancy. The statement abounds with conscious and unconscious content and mediated reflexes of the family situation, but the teacher also recognizes it as child's naivety, which makes her laugh like a joke would.

Among our respondents there are those who revealed, regardless of the presumed ethical code of their profession, that they laughed at children, "economizing on compas- 
sion" (Freud 1969: 236). (For instance, one of the teachers accidentally spilled yoghurt on a child's head, and found that funny). Some teachers react with a smile (or laughter) primarily to good-looking and amiable children who are also attached to them, which basically stresses their particularly narcissistic position. Some of the teachers laugh at the expressions of love between boys and girls and all the potential signals of possible sexual reciprocity, whereby it is difficult to make out which of these are children's naivety as a result of the hints of children's early sexuality, and which of these are psychological projections of the respondents. In general, based on the material, one can discern different psychological content of what they laugh at, which definitely influences the content and the scope of the notion of funny, including cases where the teachers witness children's laughter and the formation of a children's community of laughter. Some of the questionnaire answers are general and indefinite ("we always have a good laugh when we study diminutives"). There is always a certain reserve related to the fact that both the authors and the interpreters of the questionnaire had their subjective understanding of what is funny.

Still, the responses to the questionnaire can be partially classified and typologically interpreted at least to some extent. It is clear that there can exist a community of laughter which encompasses both the children and the teacher. A frequent object of laughter in this community is some sort of nonsense that the child utters. For instance, during preparation for the celebration of a religious holiday, the teacher asked the children: "Who is a priest?", and one of the child responded: "A person who makes you go unconscious"? The child's pun can be easily subsumed under "economizing on psychological energy" (the child has not yet completely mastered the notion of priest, and requires greater investment of psychological energy than $\mathrm{s} / \mathrm{he}$ is willing to make at that particular point, so s/he recourses to "similarity of sound"). This pun can be socialized easily, other children laugh at it to, who, also, invested certain psychological energy in mastering the notion, as well as the teacher who invests effort to explain it all to the children. Similar nonsensical examples are relatively common, and they may be conscious, a result of the child's wish to make others laugh, or a result of child's ignorance (not completely understanding certain notions), and they make both the community of children and the teacher laugh. For instance, a little girl "spoiled" a nursery rhyme on purpose, and rather than saying "grožđe, kruške, jabuke" (grapes, pears, apples) she said "grožđe, kruške, jabuške" (changing jabuke 'apples' to nonsensical jabuške, with an ending similar to kruške 'pears'), which is obviously playing, searching for rhyme, and accomplishing one's own satisfaction, and possibly even deliberately, making other children and the teacher laugh. As opposed to that, when a child was asked: "What is the name of a young of a hen and a rooster?", the child responds: "An egg", this is probably not a joke but naivety, not having mastered the term young, but everyone is laughing together, partially because a good part of the children had already mastered the notion, so that the statement by the child seems like a joke to them. Although these

${ }^{7}$ This is based on the similarity of sound between the word sveštenik 'priest' and onesvestiti 'pass out'. 
examples show certain qualitative differences, we classify both intentional and unintentional nonsenses that children make and cause common laughter by the children and the teacher as a single type of forming a community of laughter. Our research has uncovered some fifteen examples, which we therefore consider a typological tendency.

Both children and teachers are relatively frequently made to laugh by parody. Children like to imitate musicians, actors, dancers, cartoons, i.e. mostly mass-media productions, and their imitations contain parody distortion and hyperbolizing.

The main subject of our interest was, certainly, how a children's community of laughter that excludes the teacher is created. In this case, the fact that the formation and the functioning of such a community was witnessed by the teachers themselves, necessarily causes a "distortion" of the subject that we dealt with. The teachers also stated that "economizing on compassion" frequently appears with children, who collectively laugh at the clumsiness, falling, ignorance, stuttering, pulling a chair from a child about to sit down, for instance. ${ }^{8}$ In these situations the teachers most frequently do not laugh, and what excludes them from the community of laughter is, primarily, worrying that children may get hurt physically or psychologically. The fact that this self-induced exclusion of teachers from the community of laughter is related to the need to completely take on a primary professional role, which includes caring for the children's safety and well-being, pointing to the possibility that such situations draw more attention from the respondents than, for instance, children's autonomous laughter in which they play no role. This is why a quarter of responses to the question related to children's autonomous laughter (25\%) in our questionnaire is classified under this type of social and psychological situation.

Autonomous laughter of a children's community is relatively frequently connected with spontaneous play that contains certain physical activities (children splashing water in the bathroom, or catching a fly that flew into the room). ${ }^{9}$ Related to this type of spontaneity is laughter when a child taunts other children with a pronounced, usually more or less exaggerated physical activity, something that can be conditionally called a gag. For instance, our questionnaire contains 6 testimonies of a child starting a game by deliberately stumbling, falling, lunging to the floor, with other children laughing and imitating the behavior. Such playing causes general glee and a joyful atmosphere. This suggests that this type of gag is generically connected with the general glee that Korney Chukovski (1986) calls ekikiki, but this is a different type of ekikiki which is social and transcends into making others laugh.

Parody is frequently connected with this type of making others laugh. Like a gag, it is most frequently based on exaggerating and repeating a physical activity, with the only difference being greater or smaller referentiality to a mass-media content: performances

\footnotetext{
${ }^{8}$ When talking about "economizing on compassion", he talks about economizing "the energy for compassion that was already prepared in us" (Freud 1969: 236). Taking this into consideration, ostensible socially unacceptable behavior of children who are laughing at the unpleasant things happening to others can be interpreted as a stage in socialization - an announcement of their future sympathy.

${ }^{9}$ On this point cf. "Handlungsbasierte und sprachbasierte Witzpointen" (Hauser 2005: 160-165).
} 
by singers, break-dancers, cartoon characters... The community that laughs at the parody can include the teacher, but frequently does not. It seems that this depends on, on the one hand, the level of referentiality in relation to what is parodied, and on the other, on the teacher's professional role, i.e. her concern for children's safety.

Older children may also parody adult behaviors. One testimony in the questionnaire refers to a girl imitating the teacher, and thus making the other children laugh. And while a gag is frequent in younger children, parody has been testified in the middle group, and imitating the teacher in the oldest group.

Nonsense is also frequently the source of autonomous laughter in the community of children. This is, primarily, deliberate nonsense, most frequently as a conscious attempt to make other children laugh, with the teacher often being the object of laughter, and, hence, excluded from the community of laughter. A typical example of such behavior is when the teacher showed the children a big stuffed lion and asked: "What is this?" The small laughter-maker responded: "It's a worm", and the entire group laughed. The laughtermaker was joined by the other children, who deliberately said other incorrect answers, laughing. In our sample, there were fourteen examples of children playing in this way.

In some cases, the game develops into saying vulgar words - naming sexual organs and cursing. ${ }^{10}$ The escalation of children's play towards the use of vulgar words and expressions were testified 9 times by the teachers, describing children's parodies. A number of questions that come up, which can generally not be answered with certainty, deal with the social and psychological background of such behavior: are the children releasing the ballast of prohibitions related to a certain vocabulary; are they laughing at their teachers who are often surprised and have to put in additional effort to reestablish the taboo of saying inappropriate words; is this a result of the children's active interest in a sphere of life that is insufficiently discussed; does this reflect family relations ("upbringing in the home"), etc. What is certain is that children, as early as their preschool age, begin to use humor as a "means to break the norm and violate taboos" ["Witze als Mittel für Normverstösse und Tabubrüche"] (Hauser 2005: 187-199). During these "excess behaviors", children who do not use vulgar words also join in the laughter.

Children can certainly distance themselves from such behavior, but they can also take advantage of vulgar words to make other children laugh. For instance, a boy in the oldest group (a six year old) made other children laugh by saying that his brother, when playing the game Na slovo na slovo (lit. Starting with the letter, starting with the letter; similar to I spy something beginning with the letter...) primarily sought curse words starting with a particular sound. He ended with a witty "idiomatic punch line" (cf. Hauser 2005: 165-170): "He is playing Na psovku, na psovku" (i.e. I spy a curse beginning with the letter...).

This is an example of how children make each other laugh using narratives. There can be no doubt that constitution and development of a humorous narrative are evident in

${ }^{10}$ Hauser refers to this as Fäklhumor (2005: 188-192). 
children just before they start school (ages 6 to 7).11 We found twenty or so answers (those where the teacher was included in the community of laughter, and those where children laughed themselves) which are narrative-based. There are some indefinite testimonies showing that children can tell jokes well, that they can "create a good caricature", but these do not say anything about the content of the joke. Relatively frequently, children can make each other laugh by using tall stories. For instance, there is a testimony of a boy telling other children that he drove a tank and went to war, which made other children laugh. There are even examples where children retell anecdotes from their own life, making jokes, while doing so, at their own expense. For instance, a boy told a story about his father teaching him how to swim at the seaside. He wanted to take the boy's swimming armbands off, and the boy got scared, wailed in terror, and called his mother and younger sister, who is still a baby, to help him. His story made the other children laugh.

Thus, our research resulted, primarily, in the analysis of individual examples, and not in the interpretation of statistically treated variables. These examples still enable certain partially intuitive generalizations: children's laughter is frequently the consequence of play, which implies powerful physical expression and is an expression of children's general glee, where the object of laughter is not always clear. As children grow up, their laughter is increasingly based on games of what makes sense and does not make sense in language (nonsense), it is gradually culturally contextualized (parody), and, in older children, is increasingly narrative-based (joke, tall story, anecdote). Furthermore, the spontaneity of children's laughter is connected with playing, but there is also an element of children facing what Sigmund Freud calls "a critical disturbance", whereby children secure freedom through laughter which overcomes this "critical obstacle". The analysis of children's laughter reveals that prohibitions and mechanisms of psychological control that need to be overcome by laughter start in the early childhood.

\section{"FUNNY CHILDREN" BETWEEN LIFE AND BELLES-LETTERS}

The second part of our topic deals with funny children. It is an attempt to use published material (that we considered most reliable) so as to shed typological light on what adults find funny in a child's vision, experience and, above all, their interpretation of the world. We use two examples, one from the Serbian and one from the Croatian literature - Branislav Nušić's Autobiografija (Autobiography) (Nušić 1998) and Dnevnik malog Perice (The Diary of Little Perica) by Vjekoslav Majer (Majer 1978: 287-308) - to show how the socalled "children's mouths" function in literature, i.e. how these works generate humorous disharmony by combining the viewpoint of a child (be it the narrator or the focalizer) with the experience of an adult recipient. We collected material for the first part of this aspect

${ }^{11}$ On the early development of child humor and the development of child humor narrative cf. (Hauser 2005: 65-100) 
of our research from the book Olovka piše srcem ${ }^{12}$ (The pen writes with the heart) by psychologists Vanja Rupnik and Budimir Nešića, which is a collection of original, funny or poetic answers that children gave on a test of intelligence. The book collected some answers that children from the whole of Serbia gave on an intelligence test performed by the Institute of Psychology in Belgrade using the Binet-Simon scale. ${ }^{13}$ The testing included around 2000 girls and boys, aged 4 to 14, and the material is stored in the Institute's archive. In addition to a "paper" copy of the book, we also used its electronic version, ${ }^{14}$ which includes some answers that did not appear in the previous printed editions.

The authors of Olovka piše srcem emphasize that they tried to keep the material as authentic as possible; and the study is really well-documented, making it more authentic than most material that can otherwise be found online. However, what certainly undermines its authenticity making the book closer to belles-letters, is that multiple answers were put together into sections dealing with the notion that is being explained, ${ }^{15}$ and by using free flowing lines with no punctuation. This potentially makes it impossible to distinguish between individual answers, changing their context and meaning. This is a way to concentrate (and sometimes construct) what is humorous, poetic, defamiliarized, ${ }^{16}$ the research context is lost, and an pronounced artificiality is achieved, with the complex structure of the communicative situation in which these answers were initially given being suppressed.

Rupnik and Nešić are very general in describing their motivation to single out those examples that they did, by pointing out that they represent "an entire treasury", and that their "immediacy and divergence are the best illustration of children's understanding of the world" (Rupnik and Nešić 1972: 5). The authors explicitly say that, when making the selection, they "were not interested in whether these answers are only wise or only funny" (ibid.). In his Preface, Dušan Radović primarily talks about that dramatic moment "when the still undeveloped senses and consciousness meet the wide world and get to know it for the first time, part by part, and when they can identify themselves for the first time" (Radović 1972: 7). In the children's answers he sees some of his own poetic obsessions - "a childhood of words", "a lost paradise of getting to know oneself and of naming the concrete, sense-related, life-related cause for thought and word" (ibid.), the starting point of the poetic and artistic utopia: "All art is, it seems to me, an attempt to re-experience life, but in the same way as children, using those same senses and hunger, in the same rich, free and innocent way" (ibid.: 9). At the very end of his Preface, Radović points out that

\footnotetext{
${ }^{12}$ Hereinafter: Olovka.

${ }^{13}$ Selected answers, specifying the gender and age of the child, were published in 1967 and 1968 in the Svest magazine.

14 www.pefja.kg.ac.rs/preuzimanje/Materijali_za[...]/Olovka_pise_srcem.doc (accessed on 15 October 2015.); hereinafter: Olovka, web.

${ }^{15}$ The authors state: "Some of these sections are a result of multiple answers to a single question, while for others, a single answer was used" (Olovka, web).

${ }^{16}$ We use the term defamiliarization in the sense of the Russian ostranenie.
} 
it would be "even a bit wrong if these precious documents are seen simply as puns and jokes" (ibid.).

Still, the presented material and its the later reception by readers and viewers, ${ }^{17}$ clearly testify to the fact that the "originality and richness" of children's responses were primarily a cause for laughter. Why? One of the answers that first comes to mind is the warmth and tenderness caused by "all that is small", ${ }^{18}$ which mean that the source of laughter may not be humor, but rather joy, mirth and cheerfulness, in part analogously with children's ekikiki laughter. Still, this is certainly not the only possible answer. Children's answers are also funny because of real humorous disharmony, which, to a large degree, is a result of the basic characteristics of children's thinking ${ }^{19}$ during the preoperational phase. Freud showed that this disharmony often manifests itself as naivety, and that on the level of formal structure ("technique") it resembles a joke (Witz) (Freud 1969: 188).

Thus, for instance, naïve is born out of the concrete, out of children's thinking dwelling on what is visibly salient, which can result in comical demetaphorization, a literal interpretation of figurative words and phrases, as in: "zavist je kad ti na haljini konci vise" (lit. envy is when there are strings hanging from your dress, probably based on the similarity of sound of the word zavist 'envy' and visjeti 'hang') (Olovka: 38). Children's explanation of the notion of begunac 'fugitive' is wondrous, nonsensical and poetic from the point of view of the adult: "begunac je neko veliko i krivo drvo" (a fugitive is a big and crooked tree) (Olovka: 11), although, in essence, it is based on the literal meaning of the adjective kriv 'crooked' - that what is curved, with an irregular shape - which is connected, in the child's experience, with the image of a big crooked tree, whether experientially, or because the child is trying to understand and explain to him/herself the expression veliki krivac 'big culprit'. A surrealist and effective description of a difference between the wolf and a fox - "vuk menja dlaku a lisica kokoške" (lit. a wolf changes its fur, and a fox changes its chickens) - is also a testament on the literal understanding of the figurative meaning of the saying "Vuk dlaku menja, ali ćud nikad" (lit. A wolf changes its fur, but never its temper; i.e. A leopard cannot change its spots), where the child understands the verb menjati 'change' as a concrete operation of exchanging one thing for another.

The element of comical nonsense in children's explanations can also be a result of concentrating on singular, visible fragments of personal experience, which remains unexplained because of the egocentricity of the child's thinking (the notion boils down to

${ }^{17}$ In their introduction to the Internet edition, the authors refer to the 13 th edition of the book, and on 17 November 1972, a very successful play was produced by Atelje 212 based on this text, directed by Pavao Minčić.

${ }^{18}$ The expression was borrowed from the title of Radović's poem Lepo je sve što je malo (All that is small is beautiful).

${ }^{19}$ In this paper, which primarily offers literary analyses, we mention the phases based on our literature, primarily university manuals, without wanting to go into a debate about whether the differences in children and adult thought processes are primarily qualitative or quantitative (Ivić 1964; Razvojna psihologija; Korać s.a.; Pijažeova teorija kognitivnog razvoja; concrete operation stage as used in Piaget's theory of intellectual development; preoperational stage of intelligence development as used in Piaget's theory). 
the child's own representation, and his/her own way of thinking is seen as the only one possible): "begunac je jedan što ima brkove" (a fugitive is that one who has a moustache); "begunac je jedan što vata žabe" (a fugitive is that one catching frogs) (Olovka: 11). To explain why this return "to the source of language or meaning" causes an adult to laugh (or smile, whichever may be the case) is not in the least simple. It could be the enjoyment which is a result of personal infantile regression, a result of one's imaginary return to that phase of development when the meaning of words did not hamper us like it does today, but when, as for Humpty Dumpty, each word meant "just what I choose it to mean neither more nor less" (Carroll s.a.: 81).

The basis of humorous disharmony can be the incorrect understanding of a concept, and therefore, attributing sense "by the sound", children's etymology: "lakomost je kad velika kiša padne / pa odnese lako most" (greed is when there is a big rain, and it easily takes the bridge; with similarity between lakomost 'greed' and [odnese] lako most 'easily [take] the bridge') (Olovka: 53), and the torrent becomes: "ono što živi na kučku a ujeda narod" (what lives on a dog and bites people) (Olovka: 13); what is funny in the latter case is the child's ambition to define a general notion on the basis of his/her own experience, which can be visible in the image of bujica 'torrent' biting narod 'people', an abstract multitude of people. The same ambition, to use one's own understanding to give an objective definition of a concept, is visible in the answer to the question of what is izobilje 'plenty': "izobilje to je neko bilje / što se nabije u zemlju / pa posle samo izbije / i ima neko lišće / i to se bilje jede / ali nije lepo / zato što je spanać" (plenty is some sort of plants / that are put into the ground / and then it comes out itself / it has some leaves / and the leaves can be eaten / but they are not nice / because this is spinach) (Olovka: 43).

Centration, i.e. the focusing of children's thinking on the most salient aspects of a situation, an entity or an object, can also be the source of laughter: "a solider exists to shout "Yes, sir" and to have a shaved head" (Olovka: 17), or, in response to the question about the difference between an airplane and a bird: "they are the same because when I look up I can see both the bird and the airplane" (Olovka web). The centrism and egocentrism of children's thinking can also result in statements that are truly poetic from an adult's point of view. For instance, in response to the question about the difference between a wolf and a fox, the child said "the wolf is dreamt about, and the fox not necessarily", indicating the child's fears and dreams.

Humor can also result from children's transductive reasoning, "where a child reasons from one specific fact to another" (Korać s.a.: 13). For instance: "poverty is when bacon is not fat but meat" (Olovka: 66) "there is a Branko who has a head so everyone calls him bighead" (Olovka: 30), as well as from the children's attempt to move from transductive to inductive thinking: "all that has a hat is a head", or: "the head of cattle / is an elongated thing on an animal / it is useful because you can eat it / the head of a man is / a round thing on a man / it is not useful" (Olovka: 25). Of course, these examples show that certain characteristics of children's thinking never appear in their pure form, and, when laughter 
is discussed, the position of the person laughing is extremely important. A child's attempt to define a head from the point of view of usefulness can be, for instance, connected with potential skepticism of an adult who may himself/herself have certain doubts about the real usefulness of one's head in life.

Here is a child's concrete and transductive interpretation of the notion of state: "the state is when my father buys a lottery ticket and gets angry" (Olovka: 35), which can function like a hidden narrative from the point of view of an adult reader. ${ }^{20}$ It certainly opens up possibilities to imagine a situation that has been implied, whereby a child's brief statement is imbued with "a plot that is not explicitly textualized in the story but which is (in this case) implicitly indicated" (Vukićević 2013: 508), based on the experience reader. For readers who "do not share the cultural code" with the child/informer, this statement may seem more or less nonsensical, but from the point of view of those who know that lottery game losers blame the thieving state - the child's association may be both clear and funny. ${ }^{21}$ The child's criptic statement exposes the father to laughter, who grumbles to himself, unaware of the little witness listening to him, remembering and repeating what he heard in accordance with his own experience.

This position of a witness perceiving the world of adults, remembering their conversations and repeating them when s/he cannot understand their essence, can result in multiple humorous disharmony: "there are various types of cows / there is one cow / who always comes when we have guests / to ask something of Mom" (Olovka: 49). Social tactlessness of the child turns the parent's private grouching about the neighbor or the state into a public statement, and makes the child a spokesperson for what adults privately think, but do not publicly express.

\section{FUNNY CHILDREN AS LITERARY CHARACTERS AND NARRATORS}

Children's perception of the adult world, and their socially naïve testimonies, are an important factor in the humorous procedure used by writers who employ children characters in their humorous fiction. We will use limited, but, we believe, nevertheless representative

${ }^{20}$ The term hidden narrative, which we borrow from Dragana Vukićević (2015: 505-519), seemed more appropriate to us than the term paratext [Paratext] used by Porter Abott, who emphasizes that information outside the narrative (belong to the scope of the paratext) can change the narrative, without changing anything in the text itself (Porter Abott 2002: 26).

"Discovering something that is not in the text points to the ontological complexity of hidden narratives. They are ontologically bivalent like viruses - they have a negative ontological status in the text, but a positive one in the fictional mind that the reader is reconstructing. Metaphorically speaking, they make up the phantom world of the text. What we also call phantom is the plot which was not explicitly textualized in the story but (in this case) implicitly specified in tradition. Not knowing cultural conventions makes it hidden (phantom) for those readers who do not share the cultural code of the writer" (Vukićević 2015: 508).

${ }^{21}$ If we add to this the news about irregularities in lotto drawings on Serbian television, those who did not believe it, could also become the object of laughter. 
material, to attempt to typologically identify this procedure, calling it, very conditionally, "children's mouths". By introducing a child as a narrator or focalizer, the writer, generally, introduces "innocent prattle" (Andersen 1991: 106) of those who - unaware of the obstacle and not being able to see them - will openly say that the emperor is naked. Without fully understanding their nature, a child avoids social obstacles and says what the adult cannot without coming into serious social conflict. Naivety, the lack of consciousness concerning the repercussions of what is said, protects the child from understanding, and, consequently, from self-censorship. Thus, in Nušić's Autobiografija, ${ }^{22}$ the child can ask the district chief if he has a hole in the head, explaining the question by saying that "Dad says" that his brain has leaked out, and can ask a guest wearing too much make-up if she is related to Proka's mare, because her mother says that she is "as old as Proka's mare" (Nušić 1998: 275). ${ }^{23}$ The same naivety allows the child to admonish a young cousin saying that, if she does not behave, her belly will grow, because his mother explained her own pregnancy as punishment ("she was not good, and God punished her" - 1998: 276) in order to silence a child asking "awkward questions". It is the presumed naivety of the speaker that draws the line between funny and impudent.

This naivety - not understanding the world of adults - is frequently ascribed to older children in humorist prose - as is the case with Perica in Vjekoslav Majer's work; where one of the basic characteristics is freely mixing realistic developmental levels and sacrificing the realistic psychological portrayal of a character (i.e. the correspondence between development and the child's age) for the sake of creating a character that makes you laugh unknowingly, a character who hears and remembers everything but understands nothing, and therefore feels no discomfort at revealing what his loved ones are trying to conceal. In his diary, Perica reveals what the adults are keeping secret and concealing. ${ }^{24}$ For instance, at the beginning of his diary, he notes that Aunt Mina has a hoarding obsession, bordering on kleptomania, where she secretly takes toothpicks from a restaurant table multiple times. Moreover, his close observation, syncretic reasoning and juxtaposition, ${ }^{25}$ allow the adult reader to realize that the potential root of Mina's obsession is her erotic frustration: "Aunt Mina was rocking in rhythm, and while watching the mustached soldier who was pounding on the drum, she secretly put several toothpicks in her purse on the chair" (Majer 1978: 287). ${ }^{26}$ Retelling his Mom and Dad's conversation concerning volcanos works

${ }^{22}$ Which is generally emphatically artificial, reduced to a deliberately transparent mask of an adult satirical narrator.

${ }^{23}$ Old as Proka's mare is an idiom used similarly as old as Adam.

${ }^{24}$ Mother, caught in the attempt of being unfaithful, closes the windows primarily so that their argument is not heard outside.

${ }^{25}$ These are characteristics of children's prelogical thinking in the preoperational developmental stage. Syncretic reasoning refers to putting unrelated events into a whole that seems confused to an adult, a connection of unrelated things, and juxtaposition is a tendency to put two events or notions one next to another, without specifying their relations (Ivić 1964: 30-32).

${ }^{26}$ Moreover, she assumes that Fulir's "half-a-kilo-book" is a romance and sighs: "Ah, my Dubrovnik. People are so beautiful there. When you go to swim in the sea. It must have been a novel. Perhaps a romance" (Majer 1978: 287). 
in a similar way. His father's words seem to convey unintended intuition, unconscious insight into his own marital relations: "It is all boiling underground and it is unpleasant to think that right under our bed there are tall licks of flames and huge boulders of molten rock falling down with a thundering sound. It's good that this is rather deep underneath us" (Majer 1978: 296).

Perica observes the acts of adults in great detail, but does not really belong to that world. He is protected by his naivety - not being able to see the true nature of relationships between adults and the motives that drive them - he sees the family drama as an entertaining performance. Lacking any understanding or compassion, and thereby the need to "take sides" and morally evaluate what is going on, he takes away the potential pathos from events and their actors. For instance, the character of the father, with his fantasies, choleric nature, basic frustration and cowardice, is one step from the character of a humiliated and insulted little man; and the child narrator, and even his viewpoint which is physically different ${ }^{27}$ - saves the writer and reader from potentially sympathizing with such a character. From Perica's marginal point of view, the adults are simply there, and this is why he describes them as he sees them. Just like Nušić's "lively child", he also looks under the table, peeps into his parents' bedroom without hesitation, eavesdrops, hangs around his mother and Mr Fulir, ${ }^{28}$ which allows him to notice their physical closeness, comically unaware of its true nature: "Mr Fulir was very happy to have become friends with Dad and started to honor Mom much more. He sat very close to her and whispered something in her ear" or "Mr Fulir came very close to Mom and I am sure that he was saying very important things to her, because Mom kept coming closer to him" (Majer 1978: 288).

Thus, in Perica's diary, the comical is generated in two ways: The narrator himself is comical because of his naivety and ignorance: he wonders at Mom letting Mr Fulir tread on her feet under the table, which he is strictly forbidden to do, he sees the progression of her Mom's flirting without interpreting it - which turns him into someone who is an inadvertent laughter-maker (cf. Ljuštanović 2004: 23) as well as the object of laughter. At the same time, the phrases that the adults say or exchange are additionally comical in their own right because of their utter triviality, and because of the distance of the child who passes them on without evaluating or thinking about them. In essence, all the characters that Perica observes and unwittingly exposes are comical. Mr Fulir buys a book of a Dubrovnik poet by the kilo - "it is not expensive, it weighs about half a kilo, and costs only six dinars. As I had spent the money, I read it through and through" (Majer 1978: 287),

\footnotetext{
27 "I was the only one who saw it, because I am small, and I can easily see under the table" (Majer 1978: 294).

${ }^{28}$ Fulir tries in vain to persuade him to walk in front of everyone else, "like a commander": "But I did not listen to him, because everyone would see what I was doing, and I did not want that. Walking behind them, I was able to give a hard kick to a big yellow cat that was sitting on the window, and I threw a piece of stale bread, that I had in my pocket from school, into a dark room. I heard a bed creak inside, and then someone yelled 'off with you'. And then I quickly ran away" (Majer 1978: 289).
} 
his father would use an umbrella to tame a lion, and would like to be an aviator, but is afraid both of his boss and of Mr Fulir. Through Perica's observation he gets the characteristics of a typical comical boaster as well as an inhibited petty fantasizing clerk, who is envious of the moon: "That one does not pay taxes, the pig, and it is all silver" (Majer 1978: 289), thinks about volcanos and America, but does not see that his supposed best friend is courting his wife. Moreover, his stereotypical machismo and disparagement of women's wits are also funny, because vital force, as reflected in eroticism, clearly resides in his wife. The mother is also funny, with her coquetry of a pretty provincial bourgeois woman who is unhappy in her marriage, but in essence interested in keeping up appearances, as well as Aunt Mina, with her frustration, envy of her sister, and her obsession with food. Finally, Perica's ambition to keep the testimony of his family's trivial conflict for posterity is also funny.

Coincidentally, Perica himself considered funny only what he wrote about Aunt Mina (Majer 1978: 296). True, there are moments when Perica, like any child, is mischievous, breaks social taboos and enjoys it. Like the preschool children in our research, where using bad language brings satisfaction and causes laughter, Perica's satisfaction comes from delivering a "hard kick to a big yellow cat" and "throwing a piece of old bread into a dark room" (Majer 1978: 289). Both present pleasure because of unpunished violation of social norms and taboos. Still, this type of child mischief (and pleasure) is marginal in the book because, it seems to us, it serves only to confirm the identity of the narrator as a child, with the funny image of the world of adults remaining dominant. ${ }^{29}$

This has been primarily achieved by developing the character of the child narrator. Omnipresent, but without drawing the attention of the adult; precise, but unconscious of the true meaning of events, and perhaps uninterested in them, the child enables Vjekoslav Majer to build a vaudeville-like plot making it completely devoid of pathos, removing any potential element of melodrama. Pain, the adult reader suspects, is there and must be there, but the observer and recorder of events is not aware of it, and in this way temporarily spares us from feeling compassion so as to, in Freudian terms, transform the economized energy into laughter.

In developing Perica's character Majer succeeds in achieving the precious hard-todefine surplus that adds the character plasticity. In essence, Perica exposes himself through his naïve belief that before getting married he will "ask his mother first" (Majer 1978: 289); and through his belief about adulthood as a time when one can go unpunished when enjoying one's favorite childhood activities: "I am really looking forward to being a grown-up, because no one will watch me then, and I will be able to spend the entire night putting stamps in my album" (Majer 1978: 291); and, especially, in a typically childish ritual

${ }^{29}$ Nušić's "lively child" also enjoys many hyperbolic mischiefs, but what it laughs at is not mentioned. What is more, Nušić, as a type of comic contrast, emphasizes the seriousness of his "making others laugh involuntarily" and his interpretation of his own actions, as opposed to the effect that it has: "I was particularly glad that I gained a certain reputation at such an early age, and I tried, at any possible opportunity, very hard to keep it..." (Nušić 1998: 286). 
before going to sleep, which provides insight into this protected (and essentially utopian) childish world where the activities of an adult look like a funny performance, devoid of fundamental meaning:

I still say before I go to sleep: Tohumi, tohumi. These are words that I made up, and they remind me of Indian stories. [...] I always say: Tohumi, tohumi, and a pleasant fear makes me tremble, and I seem very secretive to myself. I am white, my Dad and Mom are white, but my teacher has a very brown face and big, constantly angry eyes. It always seems to me that he was an Indian, and now that the Indians have been banished, he came here to be a teacher. I must be careful that he does not peel the skin off my head, and then send me home with a peeled head. Phew, that would be terrible. Tohumi, tohumi. (Majer 1978: 291)

This indefinite fear and the insight into a child's dreams prevent potentially dehumanizing the character of the narrator, because they indirectly motivate the hyperbolic egocentrism and complete lack of compassion or fear as the marital conflict reaches its culmination: "I am very happy that this happened, because I have interesting things to put in my diary again" (Majer 1978: 304). At the same time, the dramatic conflict, when the sabre was drawn and there was a tussle, turns to nothing - the father uses his marital shipwreck as an excuse to drink, the mother closes the windows, and Perica lights a candle for Fulir, taking his father's threat literally: "I will lift him up in the air, and throw him under the tram" (Majer 1978: 307), and Aunt Mina is left without her Sunday lunch.

\section{CONCLUSION}

Our study into children's laughter, although conducted using a questionnaire with adults' interpretations and testimonies, showed that children laugh while playing, manifesting mirth induced by physical expression, and the very object of laughter generally remains unclear from the point of view of the adult (ekiki laughter). Children in the middle group base their laughter on nonsense, built deliberately and non-deliberately; on parody and gag, frequently related to "economizing on compassion", different types of breaking norms and social taboos, such as saying vulgar words and curses. In older preschool children, laughter is frequently based on narratives (jokes, tall stories, anecdotes). It has also been testified that children win freedom through laughter, by overcoming a "critical obstacle" (Freud). Thus, the analysis of children's laughter reveals that prohibitions and mechanisms of psychological control that need to be overcome using laughter start in the early childhood.

Adults, on the other hand, laugh primarily at children's naivety and its expressions "children's mouths", or things that, may seem like a pun in "technique", but rather than being a result of deliberate intention they arise from a misunderstanding or an unconscious (unknowing) violation of social norms and taboos. The laughter of adults may also be 
an expression of a feeling of fondness towards the child/children, or a consequence of somewhat narcissistic enjoyment of being in contact with beautiful and loving children who are, moreover, devoted to them. The adults' laughter is caused by different ways in which children express love to one another, and the potential signals of gender reciprocity. Nonsense, parody, puns and various types of children's comical narratives are the common object of laughter between children and adults.

In the "literarized" collection of real children's statements (Olovka piše srcem), the object of adults' laughter are children's serious attempts to explain concepts, which, because of the characteristics of preoperational thinking (centration, transduction, concreteness, naivety, egocentrism), because of etymological explanations based on sound similarity, and because of lack of social tact - come into comical disharmony with the understanding of the adults. The characters of "funny children" in literature function in much the same way. Although Majer's Perica and Nušić's child who make others laugh come close to the real laughter of a group of children, this is probably the result of the fact that their laughter, based on the fiction of what is naive, on playing, on what is nonsensical, is close in its structure to what makes children laugh. By not noticing obstacles and critical disturbances, by temporarily abolishing the terror of understanding, children's laughter to some extent comes close to what the Bakhtinian notion of the carnivalesque (Bahtin 1978: 19); it can be liberating and regenerating. Laughing together with children or laughing at children, we are, in all probability, at least partially returning to the utopia of childhood as a period of freedom from order, knowledge, understanding and compassion.

\section{REFERENCES AND SOURCES}

Andersen, Hans Christian. 1971. Bajke i priče: izbor. Zagreb: Mladost.

Andersen, Hans Christian. 1991. Sabrane bajke, 3. Beograd: Prosveta.

Andersen, Hans Christian s.a. The Emperor's New Clothes. Available at: www.andersen.sdu.dk/vaerk/ hersholt/TheEmperorsNewClothes_e.html (accessed 10 November 2016).

Bahtin, Mihail. 1978. Stvaralaštvo Fransoa Rablea i narodna kultura srednjeg veka i renesanse. Beograd: Nolit.

Bergson, Henri. 2004. O smehu. Novi Sad: Vega media.

Carroll, Lewis. 1964. Alisa u zemlji iza ogledala. Beograd: Mlado pokolenje. [Through the looking-glass and what Alice found there / Lewis Carroll https://birrell.org/andrew/alice/IGlass.pdf (accessed 10 November 2016)].

Čukovski, Kornej. 1986. Od druge do pete. Beograd: Zavod za udžbenike i nastavna sredstva.

Freud, Sigmund. 1969. Dosetka i njen odnos prema nesvesnom. Novi Sad: Matica srpska.

Hauser, Stefan. 2005. Wie Kinder Witze erzählen. Eine linguistische Studie zum Erwerb narrativer Fähigkeiten. Bern: Peter Lang.

Hegel, Georg Wilhelm Friedrich. 1986. Estetika, 3. Beograd: Beogradski izdavačko-grafički zavod. Ivić, Ivan. 1964. Dečje mišljenje. Beograd: Rad. 
Korać, Nada. s.a. Razvojna psihologija. Izabrane teme za studente pedagoškog fakulteta. Available at: www.pefja.kg.ac.rs/preuzimanje/Materijali_za_nastavu/Razvojna\%20psihologija/Razvojna_psihologija_izabrane_teme.pdf (accessed 10 October 2015).

Landsdown, Gerison. 1994. "Children's Rights". In Children's Childhoods. Observed and Experienced. Berry Mayall, ed. London: The Falmer Press.

Ljuštanović, Jovan. 2004. Dečji smeh Branislava Nušića. Novi Sad: Viša škola za obrazovanje vaspitača u Novom Sadu.

Majer, Vjekoslav. 1978. “Dnevnik malog Perice”. In Proza, 2. Nedjeljko Mihanović and Berislav Nikpalj, eds. Ljubljana, Zagreb: Delo, Globus, 287-308.

Nušić, Branislav. 1998. "Autobiografija”. Izabrana dela. Sremski Karlovci, Novi Sad: Izdavačka knjižarnica Zorana Stojanovića, 261-455.

Olovka piše srcem. Vanja Rupnik i Budimir Nešić, eds. Beograd: Beogradski izdavačko-grafički zavod. Available at: www.pefja.kg.ac.rs/preuzimanje/Materijali_za[...]/Olovka_pise_srcem.doc (accessed 15 October 2015).

Perišić, Igor. 2013. Utopija smeha. Vidovi komike i smeha u romanima Mrtve duše Nikolaja Gogolja, Uliks Džejmsa Džojsa i Zlatno runo Borislava Pekića. Beograd: Službeni glasnik.

Pijažeova teorija kognitivnog razvoja. Available at: www.pefja.kg.ac.rs/[...]/Razvojna\%20psihologija\%20 U\%20vezbe/Pijazeova\%20teorija (accessed 12 October 2015).

Porter Abbott, H. 2002. The Cambridge Introduction to Narrative. Cambridge: Cambridge University Press.

Radović, Dušan. 1959. “Dete i knjiga”. Naša deca 7-8: 10-14.

Radović, Dušan. 1972. "Predgovor”. In Olovka piše srcem. Vanja Rupnik i Budimir Nešić, eds. Beograd: Beogradski izdavačko-grafički zavod, 7-9.

Rupnik, Vanja and Budimir Nešić. 1972. "Napomena priređivača”. In Olovka piše srcem. Vanja Rupnik i Budimir Nešić, eds. Beograd: Beogradski izdavačko-grafički zavod, 5.

Souriau, Étienne. 1961. "Smijeh promatran s estetskog stanovišta". Smijeh. Uvod u naučnu studiju o smijehu, ljudskom fenomenu. Zagreb: Novinarsko izdavačko poduzeće.

Stadijum konkretnih operacija prema Pijažeovoj teoriji intelektualnog razvoja. Available at: www.fasper.bg.ac.rs/nastavnici/[...]DJ[...]/Stadijum\%2Okonkretnih\%20operacija.ppt (accessed 8 October 2015).

Souriau, Étienne. 1999. “O smešnom i komičnom, 1”. Književnost 11-12: 1926-1937.

Tomanović, Smiljka. 2004. "Sociologija o detinjstvu i sociologija za detinjstvo". In Sociologija detinjstva. Sociološka hrestomatija. Smiljka Tomanović, ed. Beograd: Zavod za udžbenike, 7-50.

Vukićević, Dragana. 2013. “Skriveni narativi”. Zbornik Matice srpske za književnost i jezik 63/2: 505-519.

Preoperacioni stadijum razvoja inteligencije prema Pijažeovoj teoriji. Available at: www.fasper.bg.ac.rs/ [...]/Preoperacioni\%20stadijum\%20razvoja\%2Ointeligencije.ppt (accessed 14 October 2015). 


\section{DJECA KOJA SE SMIJU I SMIJEŠNA DJECA: SMIJEH I RANO DJETINJSTVO}

Život djece i mladih ljudi u velikoj mjeri obilježen je smijehom. Statistički gledano, djeca se smiju mnogo više nego odrasli ljudi. Naš rad se bavi smijehom predškolske djece, načinima na koje se ona smiju i međusobno zasmijavaju u svakodnevnoj komunikaciji, kao i načinima na koje djeca tog uzrasta zasmijavaju odrasle. Pratit ćemo dječji smijeh od spontanog izražavanja i verbalizacije dobrog raspoloženja (fenomena koji Kornej Čukovski naziva "ekikiki"), preko dječjih nonsesnih dosjetki, raznih oblika fonetskog i semantičkog izokretanja i izvrtanja riječi i izraza, eufonijskih igara i dosjetki, do dječjeg vica. Pokušat ćemo pokazati kako se artikulira specifičan dječji smjehotvorni usmeno-književni kompleks, sačinjen od određenih žanrova i stilskih oblika, ali i kako se, usporedo s tim, formira smjehotvorna socijalna zajednica kod predškolske djece. S druge strane, djeca predškolskog uzrasta, svojim naivnim načinom mišljenja, uspostavljanjem neobičnih i neočekivanih simboličkih odnosa i nerazumijevanjem socijalnih realacija odraslih, često zasmijavaju odrasle. To je fenomen "dječjih usta”, koji ima svoje odjeke u usmenim žanrovima (vicu), ali i u tipovima iskaznog subjekta i fokalizatora u pisanoj književnosti (poeziji, pripovijetki, romanu).

Ključne riječi: iskazni subjekt, djetinjstvo, smijeh, smjehotvorna zajednica, dječja usta 